\title{
POTENSI IMMUNOGENIK Tetrahymena sp. (PROTOZOA: HYMENOSTOMATIDA, CILIATA) SEBAGAI ANTIGEN ANTI-ICHTHYOPHTHIRIUS MULTIFILIIS
}

\author{
Taukhid*
}

\begin{abstract}
ABSTRAK
Percobaan tentang potensi immunogenik Tetrahymena sp. sebagai antigen anti-Ichthyo. phthirius multifiliis telah dilakukan di Balai Penelitian Perikanan Air Tawar Sukamandi dan Unit Pengembangan Budidaya Air Tawar, Subang. Antigen sel utuh diberikan kepada ikan lele dumbo (Clarias gariepinus) melalui dua cara pemberian, yaitu penyuntikan intraperitoneal dan melalui pakan. Pada cara penyuntikan diterapkan empat variasi dosis antigen, yaitu 10, 20, 40 dan $80 \mathrm{mg} / \mathrm{kg}$ bobot tubuh ikan dan tanpa pemberian antigen sebagai kontrol. Pada cara pemberian melalui pakan diterapkan tiga variasi dosis antigen, yaitu $25,50,100 \mathrm{mg} / \mathrm{kg}$ pakan dan tanpa pemberian antigen sebagai kontrol. Uji immobilisasi serum darah ikan uji terhadap antigen I. multifiliis menunjukkan adanya proses induksi kekebalan (reaksi silang) diatas pengenceran $100 \mathrm{kali}$ untuk dosis $20,40 \mathrm{dan} 80 \mathrm{mg} / \mathrm{kg}$ ikan melalui penyuntikan serta dosis 50 dan $100 \mathrm{mg} / \mathrm{kg}$ melalui pakan; sedangkan pada kontrol untuk kedua kelompok pemberian antigen tersebut hanya pada pengenceran 1-2 kali. Fase mendatar (plateau) induksi kekebalan melalui penyuntikan dicapai pada minggu ke tiga sampai ke lima, sedangkan melalui pakan dicapai pada minggu ke lima sampai ke enam.
\end{abstract}

\section{ABSTRACT: Immunogenic potency of Tetrahymena sp. (Protozoa: Hymenostomatida, Ciliata) as an antigen of anti-Ichthyophthirius multifiliis. By: Taukhid.}

The study on the immunogenic potential of Tetrahymena sp. as an antigen of anti white spot disease of freshwater fishes was conducted at the Research Institute for Freshwater Fisheries, Sukamandi and the Freshwater Aquaculture Development Unit, Subang. Whole cell of antigen was given to the test fishes by means of two routes, i.e. via intra peritoneal injertion and via feed. Injection of four doses of antigen were applied as treatment i.e.: 10, 20,40 and $80 \mathrm{mg} / \mathrm{kg}$ fish body weight. Unvaccinated group was given as control. Feed administration of three doses of antigen were used as a treatment i.e.: 25,50 and $100 \mathrm{mg} / \mathrm{kg}$ fish feed and unvaccinated group as control. Immobilization test of anti serum to heterologous antigen (tomite of Ichthyophthirius multifiliis) showed that immunity induction process (cross reactivity) occurred at the dilution of more than 100 times for doses of 20,40 , and $80 \mathrm{mg} / \mathrm{kg}$ fish b.w. via injection and for doses of 50 and $100 \mathrm{mg} / \mathrm{kg}$ fish feed via feed; compared to control group for both injection and feeding, where the antibody titres were deterted only on the serum dilution of 1-2 times. The plateau of immunity induction was reached at the third up to the fifth week in the injection route and at the fifth up to the sixth week in the feed route.

KEYWORDS: Tetrahymena sp.; potential immunity; antigen; antibody titre.

\section{PENDAHULUAN}

Kasus penyakit pada ikan air tawar akibat Ichthyophthirius multifiliis atau Ich masih sering terjadi hingga saat ini terutama pada usaha pembenihan baik ikan hias maupun ikan konsumsi (Rukyani dan Taukhid, 1992). Bahkan petani ikan hias botia dan neon tetra menganggap sifat dan daya serang Ich sebagai momok yang selalu merugikan. Upaya penanggulangan secara kemoterapis telah banyak dilakukan, namun belum ada teknik yang efektif (Meyer, 1974). Parasit tersebut merupakan parasit obligat yang memiliki stadia inang dalam siklus hidupnya, berpatogenitas tinggi dan berkemampuan multiplikasi yang cepat (Lom dan Dykova, 1992). Post

*) Peneliti pada Balai Penelitian Perikanan Air Tawar 
(1983) menyatakan bahwa serangan Ich mengakibatkan $100 \%$ morbiditas dalam populasi ikan yang diikuti dengan mortalitas.

Immunoterapi terhadap Ich sudah dilaporkan oleh Bauer (1959) serta Beckert and Allison (1964) dengan menggunakan tomite Ich sebagai antigen; sementara Goven et al. (1980, 1981), Pyle (1983) serta Rukyani dan Taukhid (1992) untuk tujuan serupa menggunakan Tetrahymena pyriformis (subtropis) sebagai sumber antigen dan telah berhasil baik.

Tetrahymena sp. sudah dapat dikultur secara in vitro dan secara taksonomis berada dalam satu Sub-Ordo dengan I. multifiliis yakni Hymenostomatida, serta dapat membentuk reaksi silang dalam reaksi antigen-antibodi (Goven et al., 1981).

Dalam kolam ikan air tawar sering ditemukan genus Tetrahymena berasosiasi dengan jenis Protozoa lainnya (Puslitbangkan, 1992). Meskipun belum diketahui deskripsi spesies serta potensi immunogeniknya terhadap Ich, namun teknik kultur secara in vitro telah dilakukan oleh Rukyani et al. (1990).

Keberhasilan immunoterapi anti Ich dengan menggunakan antigen yang mudah diperoleh dan dikembangkan merupakan alternatif upaya penanggulangan penyakit Ich yang cukup prospektif.

Percobaan ini bertujuan untuk mengetahui potensi immunogenik Tetrahymena sp. sebagai antigen anti-Ichthyophthirius multifiliis sehingga dapat disusun strategi upaya penanggulangannya melalui program vaksinasi.

\section{METODOLOGI}

\section{Koleksi, Kultur dan Identifikasi}

Isolat Tetrahymena sp. diambil dari beberapa lokasi (Bogor dan Sukabumi). Isolat yang didapat dari masing-masing lokasi dimurnikan dan dibiakkan secara aksenik (axenic) menurut metode kultur yang dikembangkan oleh Rukyani et al. (1990); kemudian diidentifikasi menurut Hoffman (1967), Kabata (1985) serta Lom dan Dykova (1992).

\section{Penyiapan Antigen}

Kultur Tetrahymena sp. dilakukan dalam botol volume $250 \mathrm{~mL}$, dan diinkubasi dalam suhu kamar $\left(24-28^{\circ} \mathrm{C}\right)$ selama 5 hari. Selama 5 hari inkubasi, kepadatan Tetrahymena sp. mencapai $10^{6} \mathrm{sel} / \mathrm{mL}$.

Pemanenan dilakukan dengan memisahkan sisa-sisa metabolisme serta partikel abiotik lainnya dengan cara sentrifugasi $1.000 \mathrm{rpm}$ selama 5 menit, kemudian didiamkan selama 5 menit untuk memberi kesempatan kepada Tetrahymena sp. naik ke permukaan. Supernatan dikumpulkan, kemudian sesuai dengan cara Weir (1978); supernatan yang berisi Tetrahymena sp. ini dipanaskan dalam penangas air pada suhu $56^{\circ} \mathrm{C}$ selama $1 \mathrm{jam}$. Setelah pemanasan, supernatan disentrifugasi pada $3.000 \mathrm{rpm}$ selama 10 menit; kemudian cairan yang berwarna bening dibuang dan endapannya dicuci dengan larutan garam penyangga fosfat (Phosphate Buffered Saline) steril dan disentrifugasi lagi hingga diperoleh sediaan antigen sel utuh. Untuk mendapatkan sediaan antigen pada konsentrasi yang sesuai dengan perlakuan dosis yang hendak diterapkan, maka terlebih dahulu dilakukan penghitungan bobot kering antigen; kemudian hasilnya digunakan untuk menentukan suspensi antigen yang siap digunakan.

\section{Ikan Uji}

Jenis ikan yang digunakan adalah lele dumbo (Clarias gariepinus) berbobot tubuh antara 601$1.145 \mathrm{~g} /$ ekor atau bobot rata-rata 803 g/ekor. Selama masa adaptasi, ikan uji dipelihara dalam bak beton ukuran $6 \times 4 \mathrm{~m}^{2}$ yang dipisahkan antara jantan dan betina. Pakan yang diberikan berupa pelet dengan rasio protein $30 \%$ sebanyak $3-5 \%$ bobot tubuh per hari yang diberikan pada pagi dan sore hari.

\section{Vaksinasi}

Teknik vaksinasi pada percobaan ini dibagi menjadi dua kelompok. Pada kelompok pertama diberikan melalui penyuntikan dan satu kelompok lainnya diberikan melalui pakan.

Pada kelompok pertama, penyuntikan antigen anti-Ich dilakukan satu kali secara intraperitoneal (IP) dengan empat dosis, yaitu: (A) $10 \mathrm{mg} / \mathrm{kg}$ bobot tubuh, (B) $20 \mathrm{mg} / \mathrm{kg}$ bobot tubuh, (C) 40 
$\mathrm{mg} / \mathrm{kg}$ bobot tubuh, (D) $80 \mathrm{mg} / \mathrm{kg}$ bobot tubuh dan (E) larutan garam penyangga fosfat sebagai kontrol. Jumlah ikan uji untuk masing-masing perlakuan sebanyak 10 ekor dan dipelihara dalam satu kolam.

Vaksinasi melalui pakan diberikan dengan cara mencampur antigen ke dalam pakan. Tiga variasi dosis diterapkan pada kelompok ini, yaitu: (A) $25 \mathrm{mg} / \mathrm{kg}$ pakan, (B) $50 \mathrm{mg} / \mathrm{kg}$ pakan, (C) 100 $\mathrm{mg} / \mathrm{kg}$ pakan dan (D) tanpa penambahan antigen sebagai kontrol. Jumlah ikan uji untuk masingmasing perlakuan adalah sama seperti pada kelompok melalui penyuntikan, yaitu sebanyak 10 ekor dan dipelihara dalam satu kolam yang sama. Jenis pakan yang digunakan sebagai pembawa antigen adalah sama seperti yang diberikan selama percobaan berlangsung. Namun pada saat vaksinasi, jumlah pakan yang diberikan sebanyak $2 \%$ bobot tubuh ikan uji per hari. Pakan berantigen tersebut diberikan selama tujuh hari berturut-turut, dan sebagai pembantu perekat (binder) antigen digunakan glutan aktif (activated glutan) sebanyak $10 \mathrm{~g} / \mathrm{kg}$ pakan.

\section{Pengamatan}

Pengambilan serum darah ikan uji dilakukan setiap minggu dan berlangsung mulai minggu ke tiga setelah vaksinasi hingga minggu ke sepuluh. Sampling serum darah dilakukan dengan meng. gunakan spuit steril melalui pembuluh darah vena caudal (dorsal aorta puncture). Darah ditampung dalam tabung Eppendorf dan diproses secara hematologis untuk mendapatkan serum darah yang siap digunakan.

Pengukuran titer antibodi (cross reactivity) dilakukan secara serologis melalui teknik immobilisasi terhadap tomite Ichthyophthirius multifiliis dengan cara modifikasi metode yang dikembangkan oleh Anderson (1974), Stolen et al. (1990) dan Indrawarman (1995).

Pengenceran serial serum darah dengan larutan garam penyangga fosfat dilakukan dalam T/C 96 lubang (Titertek plates). Reaksi immobilisasi dilakukan dalam obyek gelas cekung dengan cara memasukkan $50 \mu \mathrm{l}$ serum dicampur dengan $50 \mu 1$ media yang berisi 100 sel tomite, kemudian didiamkan selama 5-10 menit pada suhu kamar (Clark et al., 1987). Pengamatan terjadinya immobilisasi dilakukan secara langsung di bawah mikroskop majemuk pada pembesaran
100-400 kali. Immobilisasi dianggap positif apabila tidak ditemukan pergerakan minimal satu sel tomite, dan dianggap negatif apabila ditemukan pergerakan minimal satu sel tomit.

\section{Analisis}

Data hasil pengamatan titer antibodi dianalisis secara deskriptif, kemudian nilai titer tertinggi dari masing-masing perlakuan pada setiap kali pengamatan ditransformasi ke dalam bentuk logaritma. Pola fluktuasi kadar antibodi dari waktu ke waktu untuk masing-masing perlakuan disajikan dalam bentuk grafik.

\section{HASIL DAN PEMBAHASAN}

Hasil pengamatan secara immunologis terhadap ikan uji yang diberi antigen Tetrahymena sp. sel utuh baik melalui penyuntikan maupun lewat pakan menunjukkan adanya proses induksi kekebalan terhadap antigen heterolog, Ichthyophthirius multifiliis. Nilai titer antibodi tertinggi dari masing-masing kelompok perlakuan yang diberi antigen melalui penyuntikan pada setiap pengamatan disajikan pada Tabel 1, dan untuk kelompok perlakuan yang diberi antigen melalui pakan disajikan pada Tabel 2.

Pembentukan reaksi silang yang cukup tinggi, yaitu diatas pengenceran 100 kali untuk dosis 20 , 40 dan $80 \mathrm{mg} / \mathrm{kg}$ ikan melalui penyuntikan serta dosis 50 dan $100 \mathrm{mg} / \mathrm{kg}$ pakan mengisyaratkan bahwa isolat Tetrahymena sp. yang digunakan pada percobaan ini memiliki potensi immunogenik terhadap antigen target.

Proses induksi kekebalan terhadap antigen heterolog pada minggu ketiga untuk kelompok ikan uji yang diberi antigen melalui penyuntikan sudah melewati fase logaritmik, dan fase puncak dicapai pada minggu ke tiga hingga ke lima untuk semua dosis yang diterapkan (Gambar 1). Sedangkan proses induksi kekebalan yang terjadi pada kelompok ikan uji yang diberi antigen melalui pakan pada saat yang sama masih berada pada fase logaritmik dan baru mencapai fase puncak pada minggu ke lima hingga ke enam untuk semua dosis yang diterapkan (Gambar 2).

Kemampuan serum darah ikan uji meng. hambat pergerakan fase infektif parasit I. multifiliis diduga karena adanya interaksi antara antibodi yang telah terbentuk dalam serum darah 
dengan permukaan parasit (Clark et al., 1987); sedangkan Goven et al., (1981) dan Tizard (1982) menduga bahwa antibodi yang terbentuk dalam serum darah akan mengadakan reaksi silang (cross reactivity) yang akan menghambat dan membatasi pergerakan tomit $I$. multifliis. Se- lanjutnya Houghton et al. (1988) mengemukakan bahwa pembatasan pergerakan akan mematikan tomite, atau kematian tersebut dapat pula disebabkan oleh "Non-specific Cytotoxic Cells $(N C C)^{\prime}$ yang mengakibatkan lisis pada tomit tersebut

Tabel 1. Titer antibodi serum darah ikan yang disuntik dengan Tetrahymena sp.

Table 1. Antibody titres of blood serum of fish injected by Tetrahymena sp.

\begin{tabular}{cccccc}
\hline \multirow{2}{*}{$\begin{array}{c}\text { Minggu } \\
\text { Week }\end{array}$} & \multicolumn{5}{c}{$\begin{array}{c}\text { Dosis (Dosage) } \\
(\mathbf{m g} / \mathbf{k g ~ b . w . )}\end{array}$} \\
\cline { 2 - 6 } & $\mathbf{0}$ & $\mathbf{1 0}$ & $\mathbf{2 0}$ & $\mathbf{4 0}$ & $\mathbf{8 0}$ \\
\hline 3 & 0.4771 & 0.9542 & 2.1072 & 2.4099 & 3.0107 \\
4 & 0.4771 & 1.2304 & 2.4099 & 2.4099 & 3.0107 \\
5 & 0.3010 & 1.2304 & 1.8129 & 2.7101 & 3.0107 \\
6 & 0.3010 & 0.9542 & 1.5185 & 2.1072 & 2.7101 \\
7 & 0.3010 & 0.9542 & 1.5185 & 1.8129 & 2.1072 \\
8 & 0.3010 & 0.6990 & 1.2304 & 1.2304 & 1.5185 \\
9 & 0.3010 & 0.6990 & 0.9542 & 0.9542 & 0.9542 \\
10 & 0.3010 & 0.6990 & 0.6990 & 0.9542 & 0.9542 \\
\hline
\end{tabular}

Angka di atas adalah angka mingguan tertinggi yang didapat dari setiap pengujian dan telah ditransformasi dalam log (titer +1$)$ The numbers above are the highest degrees obtained weekly of each treatment and have been transformed into log (titre +1$)$

Tabel 2. Titer antibodi serum darah ikan yang diinfeksi dengan Tetrahymena sp. melalui pakan

Table 2. Antibody titres of blood serum of fish vaccinated by Tetrahymena sp. administered through feed.

\begin{tabular}{ccccc}
\hline \multirow{2}{*}{$\begin{array}{c}\text { Minggu } \\
\text { Week }\end{array}$} & \multicolumn{4}{c}{$\begin{array}{c}\text { Dosis }(\mathbf{m g} / \mathbf{k g} \text { pakan) } \\
\text { Dosage }(\mathbf{m g} / \mathbf{k g} \text { feed) }\end{array}$} \\
\cline { 2 - 5 } & $\mathbf{0}$ & $\mathbf{2 5}$ & $\mathbf{5 0}$ & $\mathbf{1 0 0}$ \\
\hline 3 & 0.3010 & 0.9542 & 1.2304 & 1.5185 \\
4 & 0.3010 & 1.2304 & 1.2304 & 1.8129 \\
5 & 0.3010 & 1.8129 & 2.1072 & 2.1072 \\
6 & 0.3010 & 1.2304 & 1.8129 & 2.1072 \\
7 & 0.3010 & 0.6990 & 1.2304 & 1.2304 \\
8 & 0.3010 & 0.6990 & 0.9542 & 0.9542 \\
9 & 0.3010 & 0.6990 & 0.6990 & 0.6990 \\
10 & 0.3010 & 0.6990 & 0.6990 & 0.6990 \\
\hline
\end{tabular}

Angka di atas adalah angka mingguan tertinggi yang didapat dari setiap pengujian dan telah ditransformasi dalam log $($ titer +1$)$

The numbers above are the highest degrees obtained weekly of each treatment and have been transformed into log (titre +1$)$ 
Kekebalan tubuh ikan air tawar terhadap infeksi parasit I. multifiliis sudah diketahui sejak Buschkiel (1910) dalam Lom dan Dykova (1992), dimana sebagian ikan yang bertahan hidup setelah terjadi infeksi akan menjadi kebal dan efektivitas kekebalan tersebut sangat tergantung pada saat awal intensitas penyerangan. Kekebalan spesifik ini dapat berlangsung cukup lama, yaitu antara 7-8 bulan (Hines dan Spira, 1974; serta Wahli dan Meier, 1985). Serum darahnya mampu menghambat pergerakan tomit hingga pengenceran ke-1024 kali (Hines dan Spira, 1974).

Immunoterapi anti-ichthyophthiriasis sudah banyak dilakukan, baik dengan menggunakan antigen homologous (Bauer, 1959; Beckert dan Allison, 1964; dan Indrawarman, 1995); antigen yang heterolog (Goven et al., 1980, 1981a, 1981b; Wolf dan Markiw, 1982; Pyle, 1983; Nainggolan, 1990; Rukyani dan Taukhid, 1992); antibodi monoklonal (Dickerson et al., 1986) maupun menggunakan vitamin $\mathrm{C}$ (ascorbic acid) (Wahli et al., 1985). Dari keseluruhan material yang digunakan, penggunaan antigen heterologous Tetrahymena sp. dianggap cukup efektif serta tetap memiliki tingkat proteksi yang baik.

Beberapa spesies Tetrahymena fakultatif parasitik telah terbukti bersifat immunogenik terhadap ichthyophthiriasis, diantaranya $T$. pyriformis (Goven et al., 1981b), Rukyani dan Taukhid (1992); T. thermophilia (Wolf dan Markiw, 1982) dan diduga beberapa spesies lainnya juga memiliki potensi yang sama seperti $T$. corlissi, $T$. rostrata maupun T. faurei (Lom dan Dykova, 1992).

Keseluruhan spesies Tetrahymena spp. yang digunakan oleh beberapa peneliti di atas sebagai sumber antigen anti-ichthyophthiriasis diisolasi dari perairan subtropis. Sedangkan Tetrahymena sp. yang digunakan pada percobaan ini merupakan hasil isolasi dari air kolam di daerah Sukabumi, Jawa Barat dan pada tulisan ini disebut Tetrahymena lokal (IS-1) dan belum diidentifikasi hingga tingkat spesies. Meskipun demikian, ternyata kemampuan immunogeniknya cukup baik, di mana pada antiserum pengenceran rendah mampu mengaglutinasi antigen target dan pada pengenceran tinggi mampu menghambat pergerakan antigen target. Hal ini sesuai dengan hasil yang diperoleh Dickerson et al. (1986) yang telah meneliti potensi immunogenik tiga isolat Tetrahymena spp. Ketiga isolat tersebut tidak menampakkan adanya efek yang berbeda dalam proses perangsangan perlindungan, namun menunjukkan adanya perbedaan terhadap tingkat perlindungan hewan uji yang diberi isolat berbeda terhadap Ich .

Hasil pengamatan immunologis yang dilakukan Goven et al. (1981b) dengan menggunakan teknik "Fluorescent Antibody Techniques (FAT)" terhadap dua antigen siliata, yaitu Tetrahymena spp. dan I. multifiliis menunjukkan adanya reaksi silang yang terletak pada sepanjang silia dan mengelilingi pelikel dari kedua organisme tersebut. Demikian pula hasil pengamatan mikroskop elektron terhadap beberapa silia dari beberapa spesies siliata, ternyata memiliki kesamaan bahan dasar sebagai unsur esensial dan dari silia yang telah diekstrak (substruktur) menunjukkan bahwa semua bagian silia merupakan penentu antigenik (Goven et al., 1981b).

Beberapa peneliti terdahulu yang menggunakan antigen yang heterogen sebagai sumber antigen lebih banyak menekankan pada aspek proteksi ikan uji setelah diuji tantang dengan target sasaran ataupun setelah dipelihara beberapa saat. Sedangkan pada percobaan ini, selain dilakukan pengamatan terhadap eksistensi antibodi yang dinyatakan dalam kadar titer antibodi, juga terhadap tempo peluruhan antibodi tersebut. Dari kedua teknik pemberian, yaitu melalui penyuntikan dan pakan untuk semua dosis yang diterapkan, antibodi masih terdeteksi hingga minggu ke sepuluh pasca immunisasi $( \pm 2$ bulan) (Gambar 1 dan 2). Tempo peluruhan antibodi tersebut masih lebih singkat bila dibandingkan dengan induksi kekebalan yang diperoleh melalui proses immunisasi alamiah oleh antigen yang homolog, di mana antibodi masih terdeteksi hingga 7.8 bulan (Hines dan Spira, 1974) dan (Wahli dan Meier, 1985). Namun untuk beberapa jenis ikan budidaya air tawar di Indonesia, di mana umur yang rentan umumnya pada saat benih dan masa pemeliharaan yang biasanya berlangsung satu hingga dua bulan maka tempo peluruhan tersebut sudah cukup untuk melindungi infeksi parasit tersebut selama masa kritis.

Induksi kekebalan yang terjadi pada kelompok ikan yang diberi antigen melalui penyuntikan relatif lebih tinggi dibandingkan dengan induksi 
Taukhid

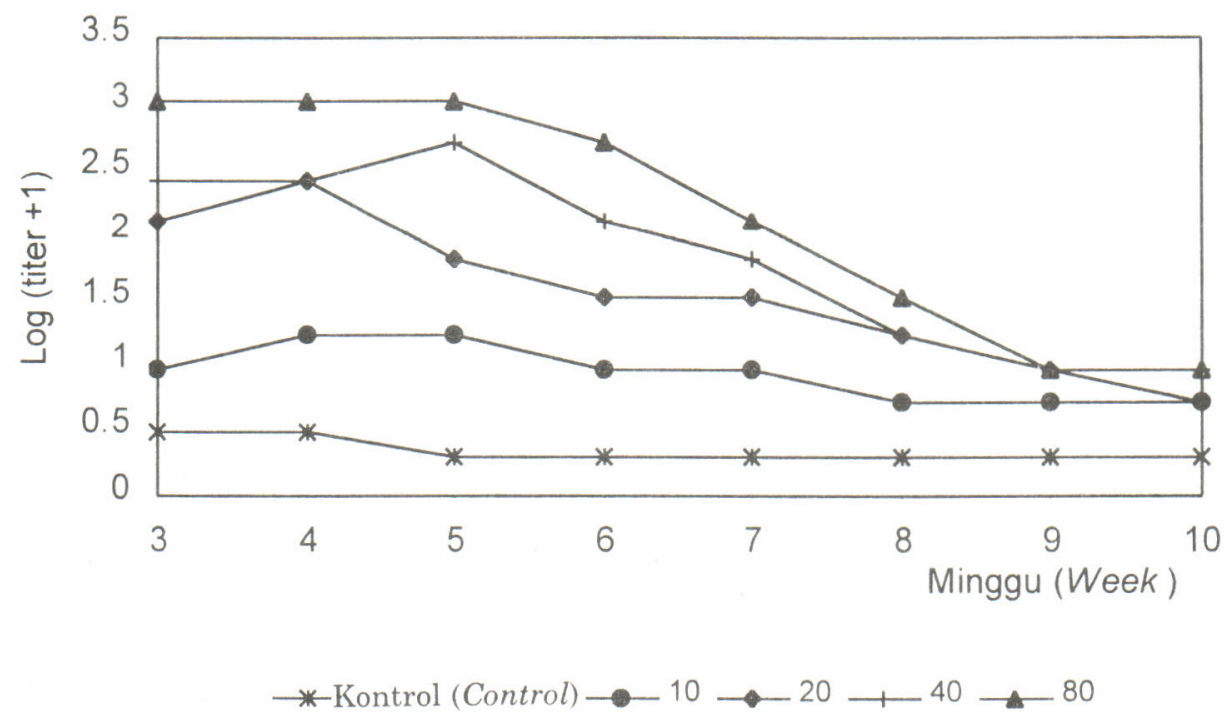

Gambar 1. Titer antibodi anti-Ichthyophthirius multifiliis dalam serum darah ikan yang diinfeksi Tetrahymena sp. melalui suntikan.

Figure 1. Antibody titre of anti-Ichthyophthirius multifiliis on blood serum of catfish vaccinated by Tetrahymena sp. administered through injection.

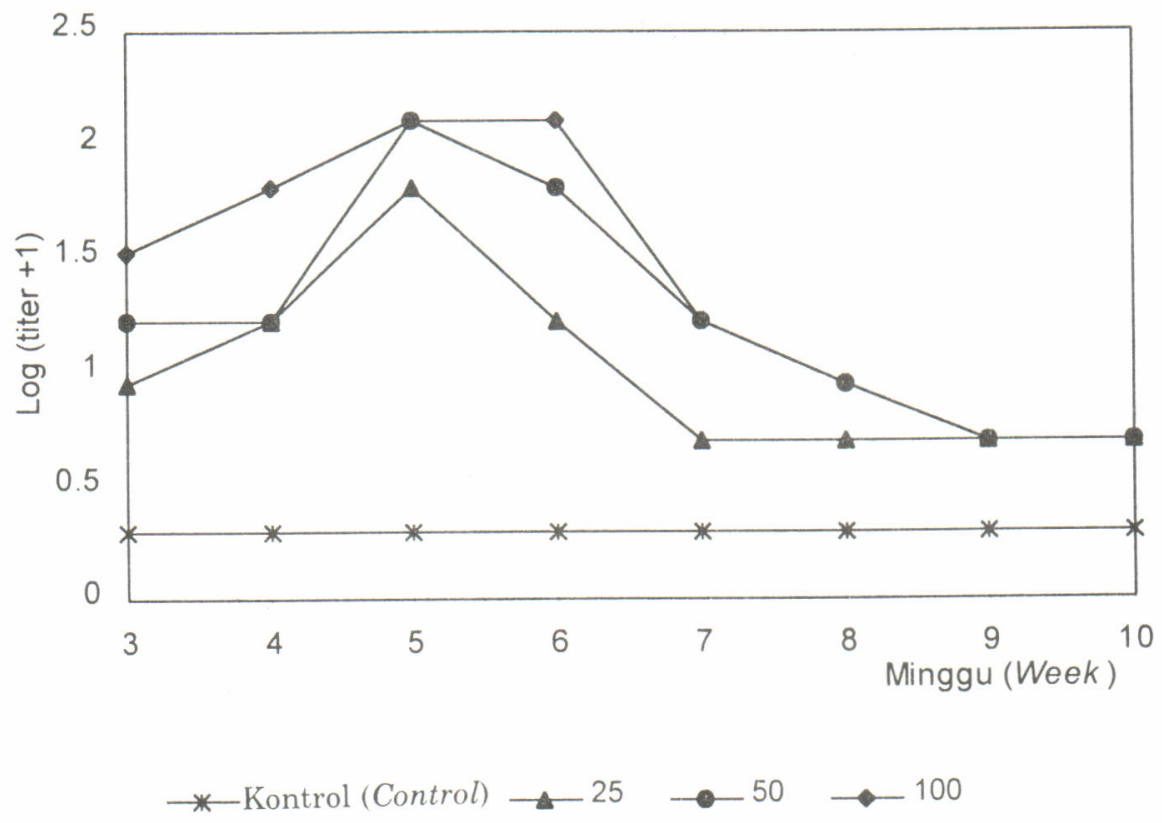

Gambar 2. Titer antibodi anti-Ichthyophthirius multifiliis dalam serum darah ikan yang diinfeksi Tetrahymena sp. melalui pakan.

Figure 2. Antibody titre of anti-Ichthyophthirius multifiliis on blood serum of catfish vaccinated Tetrahymena sp. administered through feed. 
kekebalan yang dicapai pada kelompok yang diberi antigen melalui pakan. Hal ini sangat logis, karena antigen yang diberikan melalui penyuntikan dapat dikatakan $100 \%$ akan masuk dan berperan dalam proses pembentukan antibodi. Sedangkan pada kelompok yang diberi antigen melalui pakan, di samping akan dipengaruhi oleh faktor internal seperti pada pemberian melalui penyuntikan, juga faktorfaktor lain yang menyangkut efisiensi: proses pencucian, nafsu makan, peluang mendapatkan pakan berantigen serta efisiensi biologis dalam proses pencernaan. Ellis (1988) pun mengemukakan bahwa immunisasi ikan melalui penyuntikan intraperitoneal merupakan cara yang paling efektif, sedangkan route intramuskular jarang dilakukan karena sering menimbulkan bekas luka atau birat pada urat daging yang tidak sedap dipandang mata, selain itu juga sering timbul kebocoran dari inokulum sebelum diabsorbsi.

Proses induksi kekebalan yang terjadi pada kelompok ikan uji yang diberi antigen melalui penyuntikan memiliki respon tanggap kebal buatan yang lebih cepat serta kadar antibodi yang lebih tinggi dibandingkan dengan kelompok ikan uji yang diberi antigen melalui pakan (Gambar 1 dan Gambar 2). Hal ini terjadi karena antigen yang diberikan melalui penyuntikan akan langsung menyebar ke dalam sistem sirkulasi darah, sehingga memicu sel-sel kompeten serta organ pembentuk antibodi untuk segera bekerja. Sedangkan pada pemberian melalui pakan, antigen tidak langsung dapat ditangkap oleh selsel kompeten yang berhubungan dengan sistem kekebalan, sehingga respon tanggap yang terjadi juga akan lebih lambat. Sedangkan kadar titer antobodi yang terbentuk pada pemberian lewat pakan akan dipengaruhi oleh beberapa faktor seperti pencucian, kerusakan pada saat proses penempelan serta efisiensi biologis pada tubuh ikan, sehingga kadar titer yang terbentuk relatif lebih rendah dibanding lewat penyuntikan.

Tanpa menilai keunggulan ataupun kekurangan teknik pemberian, Tetrahymena lokal cukup prospektif sebagai sumber antigen antiichthyophthiriasis. Teknik immunisasi pada ikan budidaya yang sudah umum dilakukan selain kedua teknik tersebut, misalnya immunisasi melalui perendaman merupakan teknik yang relatif lebih mudah dan murah. Namun untuk perendaman dalam larutan antigen Tetrahymena yang sel-selnya memiliki ukuran yang relatif besar $(25-50 \mu \mathrm{m})$, nampaknya masih perlu kajian terhadap "Extra cellular products (ECP)"-nya maupun pemecahan sel (sonified antigen) sebagai sediaan antigen.

\section{KESIMPULAN}

Isolat Tetrahymena sp. yang digunakan dalam percobaan ini memiliki potensi immunogenik (dapat bereaksi silang dengan antigen sasaran) dan dapat digunakan sebagai antigen heterogen anti-ichthyophthiriasis pada ikan air tawar.

Dari kedua teknik pemberian antigen yaitu melalui penyuntikan dan pakan, nampak adanya sifat kumulatif respon induksi kekebalan terhadap dosis antigen yang diberikan.

Titer antibodi hasil uji immobilisasi serum darah ikan uji terhadap agent target masih terdeteksi pada pengenceran lebih dari $100 \mathrm{kali}$ diperoleh pada dosis 20, 40 dan $80 \mathrm{mg} / \mathrm{kg}$ ikan melalui penyuntikan serta 50 dan $100 \mathrm{mg} / \mathrm{kg}$ melalui pakan.

Fase mendatar (plateau) induksi kekebalan dicapai pada minggu ke tiga sampai ke lima pasca immunisasi untuk kelompok yang diberi antigen melalui penyuntikan dan pada minggu ke lima sampai ke enam untuk kelompok yang diberi antigen melalui pakan.

Tempo peluruhan dari kedua teknik pemberian tersebut untuk semua dosis yang diterapkan nampaknya relatif pendek, meskipun masih terdeteksi pada minggu ke sepuluh.

\section{UCAPAN TERIMA KASIH}

Penulis mengucapkan terima kasih kepada Saudara Bambang Priadi atas bantuan dan kerjasamanya baik di lapangan maupun di laboratorium, juga kepada Kepala dan staf Unit Pengembangan Budidaya Air Tawar, Subang atas segala bantuannya di lapangan.

\section{DAFTAR PUSTAKA}

Anderson, D.P. 1974. Fish immunology and disease of fishes. T.F.H. Publication, Inc. Ltd, Hongkong.

Bauer, O.N. 1959. Immunity of fish occuring in infections with Ichthyophthirius multifiliis. Dokl. Akad. Navk USSR, 93: 377-379. 
Beckert, H. and R. Allison. 1964. Some host responses of white catfish to Ichthyophthirius multifiliis, Fouquet. Proc. 18th Ann. Meet. Southe. Assoc. Game and Fish Comm., 18: 438-441.

Clark, T.G.; H.W. Dickerson; J.B. Gratzek and R.C. Findly. 1987. In vitro response of Ichthyophthirius multifiliis to sera from immune channel catfish. J. Fish Biol. 31 (Supplement A): 203-208.

Dickerson, H.W.; Evans, D.L. and Gratzek, J.B. 1986. Production and preliminary characterization of murine monoclonal antibodies to Ichthyophthirius multifiliis, a protozoan parasite of fish. Am. J. Vet. Res., 47: 2400-2404.

Ellis, A.E. 1988. General principles of fish vaccination dalam Fish Vaccination. Academic Press, London. hal 1.19.

Goven, B.A.; D.L. Dawre; and J.B. Gratzek. 1980. Protection of channel catfish, Ictalurus punctatus Rafinesque, against Ichthyophthirius multifiliis Fouquet, by immunization. J. Fish. Biol., 17: 311 . 316 .

Goven, B.A.; D.L. Dawe; and J.B. Gratzek. 1981a. Protection of channel catfish (Ictalurus punctatus) against Ichthyophthirius multifiliis (Fouquet) by immunization with varying doses of Tetrahymena pyriformis (Lwoff) cilia. Aquaculture, 23: 269-273.

Goven, B.A.; D.L. Dawe; and J.B. Gratzek. 1981b. In vitro demonstration of serological cross-reactivity between Ichthyophthirius multifiliis Fouquet and Tetrahymena pyriformis Lwoff. Developmental and comparative immunology, Vol. 5, p 283-289.

Hines, R.S. and D.T. Spira. 1974. Ichthyophthiriasis in the mirror carp, Cyprinus carpio (L). V. Acquired immunity. J. Fish Biol. (6): 373-378.

Hoffman, G.L. 1967. Parasites of North American freshwater fishes. University of California Press, Los Angeles.

Houghton, G.; R.A. Mattew; and J.E. Harris. 1988. Vaccination against Protozoan and Helminth Parasites of Fish. Academic Press. London.

Indrawarman, I. 1995. Peran antibodi induk pada anak ikan tilapia, Orechromis niloticus dan $O$. mossambicus terhadap ichthyophthiriasis. Thesis. Program Pasca Sarjana, Institut Pertanian Bogor. Bogor. 54 hal.

Kabata, Z. 1985. Parasites and diseases of fish cultured in the tropics. Taylor and Francis. London and Philadelphia.

Lom, J. and I. Dykova. 1992. Protozoan parasites of fishes. Developments in aquaculture and fisheries science, Vol. 26. Elsevier Amsterdam-London-New York-Tokyo. $315 \mathrm{p}$.
Meyer, F.P. 1974. Parasites of freshwater fishes II. Protozoa 3. Ichthyophthirius multifiliis. U.S. Fish and wild. Serv. F.D.L. 2. 5 p.

Nainggolan, D.N. 1990. Penelitian immunisasi penyakit bintik putih pada ikan lele dumbo (Clarias gariepinus) dengan vaksin Tetrahymena pyriformis. Skripsi, Fakultas Kedokteran Hewan, Institut Pertanian Bogor.

Post, G.W. 1983. Texbook of fish health. T.F.H. Publication. Neptune Cyty, N.J. 256 p.

Puslitbangkan. 1992. Distribusi geografis jasad patogen pada ikan dan udang di Pulau Jawa, Bali dan Sumbagsel. (Laporan intern).

Pyle, S.W. 1983. Antigenic and serologic relationships between Ichthyophthirius multifiliis Fouquet and Tetrahymena pyriformis Lwoff. PhD Dissertation (Abstract). Univ. of Georgia.

Rukyani, A.; Taukhid dan O. Roganda. 1990. Kelimpahan populasi Tetrahymena sp. dan Tetrahymena pyriformis dalam kultur murni di laboratorium. Bull. Penel. Perik. Darat Bogor Vol. 9 No. 2 hal 1-8.

Rukyani, A. dan Taukhid. 1992. Ketahanan benih ikan lele dumbo (Clarias gariepinus) terhadap serangan parasit Ichthyophthirius multifiliis dengan pemberian vaksin Tetrahymena pyriformis. Bull. Penel. Perik. Darat Bogor Vol. 11 No. 2: 168-174.

Stolen, J.S.; T.C. Fletcher; D.P. Anderson; B.S. Roberson; W.B. van Muiswinkel. 1990. Techniques in fish immunology. Fish Immunology Technical Communication No. 1. SOS Publications.

Tizard, I.R. 1982. An introduction to veterinary immunology. W.B. Saunders Company, Philadelphia.

Wahli, T. and Meier, W. 1985. Ichthyophthiriasis in trout: Investigation of natural defence mechanisms. In: Ellis, A.E. (Ed.), Fish and shellfish pathology. Academic Press, Orlando, Flor., 403 p.

Wahli, T.; Steiff, K.; and Meier, W. 1985. Influence of ascorbic acid on Ichthyophthirius multifiliis infections in trout. Bull. Eur. Ass. Fish Pathol., 5: 86-87.

Weir, D.M. 1978. Handbook of experimental immunology. Department of Bacteriology. University of Edinburgh, London.

Wolf, K. and M.E. Markiw. 1982. Ichthyophthiriasis: immersion immunization of rainbow trout, Salmo gairdneri using Tetrahymena thermophilia as a protective immunogen. Can. J. Fish. Aquat. Sci., 39: 1722-1725. 